\title{
Effects of Grasshopper Meal in the Diet of Clarias Gariepinus Fingerlings
}

\section{Olaleye Ibukun Grace*}

Fisheries and Aquaculture unit, Institute of Oceanography, University of Calabar, Cross River State, Nigeria

\begin{abstract}
A study was conducted to assess the effects of grasshopper meal in the diet of Clarias gariepinus fingerlings. The aim was to substitute fishmeal with grasshopper meal in the formulation of Clarias gariepinus fingerlings feed Feeds were formulated using different quantities of fishmeal and grasshopper meal and were used in feeding Clarias gariepinus fingerlings. Result shows that the best growth and feed utilization indices were recorded in the fingerlings fed $20 \%$ fishmeal and $10 \%$ grasshopper meal followed by those fed $15 \%$ fishmeal and $15 \%$ grasshopper meal. The least growth rate was recorded in fingerlings fed only $30 \%$ grasshopper meal. It could be concluded that Clarias fed with diet containing $10 \%$ grasshopper meal combined with $20 \%$ fishmeal produced the best growth rate.
\end{abstract}

Keywords: Growth; Grasshopper meal; Clarias gariepinus; Fingerling

\section{Introduction}

Fish is the major source of protein for most Nigerians. The increasing human population and the desire to obtain a nutritionally balanced level of protein intake is a major cause of the high fish demand in Nigeria. Aquaculture which is expected to bridge the gap between fish supply and demand is constrained generally by inappropriate technologies [1].

Fish feed is presently very expensive; both imported and locally produced ones. This is among the problems facing successful aquaculture in Nigeria coupled with good quality fish Falaye $[2,3]$. This is as a result of the competing need of the agricultural produce and by-products between man and livestock Salami et al. [4] and between livestock and fish in the formulation and production of the animal feed. Various protein sources have different amino acids, both essential and non-essential. A deficiency of one or more of these essential nutrients results in reduced growth rate, depressed diet, disease or even death NRC [5].

In the last decade, much effort has been made with the use of soybean meal as a good alternative to fishmeal in the diet of Clarias gariepinus [6-12]. Many researchers have attempted to use varied substitutes to fishmeal in Clarias gariepinus production with varying results. Faturoti and Oyelese [13] found yellow maize and sweet potato as a good energy source in the diet of Clarias gariepinus while, Eyo [14] obtained poor growth rate while feeding Clarias anguillaris with soybean diet. Ufodike and Ekokotu [15] confirm that excess levels of dietary protein might retard fish growth due to energy expenditure in deamination and excretion of excess protein. Ofojekwu and Ejike [16] also obtained poor results with cottonseed meal in Clarias food.

Edible Grasshoppers and locusts which include Nomadacris septemfasciata, Kraussaria sp., Katantop sp., Anacridium sp., Cataloipus sp., Hieroglyphycus sp., Gelestorhinus sp., and Locusta sp. are found to invade most of the North-eastern and Central States of Nigeria at a particular season of the year causing great consequences on crops Sharah [17]. These grasshoppers also serve as a delicacy to nation of North Eastern Nigeria during these invasions. These grasshoppers are as rich as the fishmeal in terms of its amino acid profile (Table 1). Encouraged by the similarity in the quality of the amino acid profile of fish and grasshopper meal, this research decided to replace fishmeal with grasshopper meal to ascertain if these qualities of the grasshopper can compare favorable in growth production of Clarias gariepinus as that obtained or fishmeal in the same species.

\section{Materials and Methods}

\section{Preparation of grasshopper meal}

Samples of edible grasshoppers and locusts were collected from the market located in Maiduguri irrespective of their sizes and species. The samples were dewinged, all appendages removed, sundried and crushed into powder with milling machine. Proximate analysis of the powdered samples was performed using standard methods AOAC [18]. Fibre content was assessed according to Cullison. The protein was measured by calorimetric method (Vanadomolybdale yellow method) (Table 2) with a varian 634UV visible spectrometer. Crude protein was calculated as total Kjeldahl N x 6.25.

\section{Experimental diet}

The feedstuffs used were obtained locally within Maiduguri town. The soybean was toasted for 15 minutes according to Eyo [14]. Other ingredients such as groundnut cake, fishmeal, yellow maize, maize bran were obtained and ground into powder with the toasted soybean and grasshopper. A $45 \% \mathrm{cp}$ feed was obtained from the combination of the feed ingredient in the diet and mixed with the premix.

Different diets (those containing only fishmeal and those containing grasshopper meal at various inclusion levels) were formulated using different treatments which include feed containing only fishmeal, feed containing only grasshopper meal and feed containing both fishmeal and grasshopper meal. The feed was pelleted using kitchen hand cranker. The pelleted feed was crushed into crumbles before administering them to the fish.

\section{Experimental design and treatments}

Fingerlings weighing between 15-20 g were obtained from the hatchery and conditioned in net hapa $(1 \mathrm{~m} \mathrm{x} 1 \mathrm{~m} \times 1.2 \mathrm{~m})$ installed in

*Corresponding author: Olaleye I.G, Fisheries and Aquaculture unit, Institute of Oceanography, University of Calabar, Cross River State, Nigeria, Tel: 6285213396636; E-mail: bknonair@gmail.com

Received January 16, 2015; Accepted January 30, 2015; Published February 15,2015

Citation: Olaleye I.G (2015) Effects of Grasshopper Meal in the Diet of Clarias Gariepinus Fingerlings. J Aquac Res Development 6: 321 . doi: 10.4172/2155-9546.1000321

Copyright: (c) 2015 Olaleye I.G. This is an open-access article distributed under the terms of the Creative Commons Attribution License, which permits unrestricted use, distribution, and reproduction in any medium, provided the original author and source are credited. 


\begin{tabular}{|c|c|c|}
\hline Amino acid & Fish meal & Grasshopper meal \\
\hline Lysine & 7.85 & 5.87 \\
\hline Histidine & 2.22 & 4.24 \\
\hline Arginine & 5.82 & 7.62 \\
\hline Aspartic & 9.35 & 9.32 \\
\hline Threonine & 4.55 & 4.08 \\
\hline Serine & 4.55 & 5.22 \\
\hline Glutamic & 13.3 & 15.21 \\
\hline Proline & 4.35 & 5.02 \\
\hline Glycine & 5.90 & 4.78 \\
\hline Alanine & 6.34 & 5.29 \\
\hline Cysteine & 0.70 & 1.79 \\
\hline Valine & 5.65 & 3.47 \\
\hline Methionine & 2.84 & 1.96 \\
\hline Isoleucine & 4.85 & 4.21 \\
\hline Leucine & 7.35 & 5.30 \\
\hline Tyrosine & 3.45 & 2.88 \\
\hline Phenylalanine & 4.35 & 4.50 \\
\hline
\end{tabular}

SOURCE: Okoye(2003).

Table 1: Comparative Amino acid profile of the proteins of fishmeal and grasshopper meal

\begin{tabular}{|c|c|}
\hline FEEDSTUFFS & \%INCLUSION LEVEL \\
\hline Yellow maize & 10.11 \\
\hline Groundnut cake & 25.80 \\
\hline Soybean meal & 25.80 \\
\hline Fishmeal/grasshopper meal & 30 \\
\hline Cassava tuber starch & 5 \\
\hline Premix (vitamin) & 2 \\
\hline Salt & 0.29 \\
\hline Bone & 1 \\
\hline Total & 100.00 \\
\hline
\end{tabular}

Table 2: Product file for formulating $45 \%$ crude protein for Clarias gariepinus

$11 \mathrm{~m} \times 10 \mathrm{~m} \times 1.2 \mathrm{~m}$ concrete tank for 48 hours. The fish were stocked at 10 fish per meter square. Five different diets were tried with two replicates for each treatment for a period of 56 days. Below is a table showing the different treatments inclusion level (Table 3).

Fish in all treatments were fed 5\% of their body weight daily split into two feeding frequency and the weight were recorded bi-weekly. Feeding rate was adjusted weekly based on body weight. Water quality parameter such as temperature and $\mathrm{pH}$ were monitored.

At the end of the research, weight gained (g), daily average growth rate (ADG), specific growth rate (SGR), food conversion rate (FCR) and protein efficiency ratio (PER) were calculated.

\section{Data analysis}

Data obtained from the trials were subjected to one way analysis of variance and statistical different between the means were separated using Turkey-HSD at 95\% degree of confidence using SPSS 15.0 statistics package.

\section{Results}

\section{Key}

TFC=Total Feed Consumed, ADG=Average Daily Growth, SGR= Specific Growth Ratio, FCR=Food Conversion Ratio and PER=Protein Efficiency Ratio.

Means with the same superscripts along columns are not significantly different $(\mathrm{p}>0.05)$.

\section{Discussion}

The result of the nutrient composition shows that grasshopper meal has high crude protein of 64.51 . This is a very high value that could completely replace fishmeal in fish feed. The value compares favorably with the result obtained by Njidda and Isadahomen [19] which was $64.32 \%$ cp. This value of grasshopper compares with that of fishmeal obtained by Okoye [20] from clupeid with $68.47 \% \mathrm{cp}$. The ether extract was 12.0 and closely related to that reported by Njidda and Isadahomen [19]. The value of the ether extract of grasshopper meal is greater than that obtained in fishmeal (Tables 4-6). This is good as it is being used as component of encapsulment of feed nutrient meant for fish to prevent loss of water soluble nutrients such as proteins and amino acids because of its insoluble property in water Lopez-Alverado et al. [21]. The crude fibre content was high due to the fact that grasshopper has an exoskeleton made of chitin Okoye and Nnaji [20]. The Nitrogen free extract was 5.49 which is the small amount of carbohydrates that can be digested easily because of its solubility Falayi $[2,3]$. The dry matter of grasshopper meal is very high 94.9 with low moisture content of 5.1. This implies quick drying of the feed compared to dry matter of fishmeal 90.0 and moisture content of $10 \%$ according to Eyo [22].

The calcium content is greater than those obtained from soybean meal and groundnut cake. It compares favorably with that of bloodmeal and less than that of fishmeal Haruna [23]. The phosphorus content is low due to low ash content. The sodium content compares favorably with that of soybean meal and yellow maize which has being used to replace fishmeal obtained by different researchers. The potassium content compares favorably with that of fishmeal obtained by Haruna [23]. The above nutrients composition of grasshopper meal and its quality makes it a good dietary supplement in fish feed production.

The result of the study shows that Treatment 2 (20\% fishmeal and $10 \%$ grasshopper meal) has the highest weight gain, Average daily weight gain(ADG), Specific growth rate(SGR), Protein efficiency ratio(PER) and high Food conversion ratio(FCR) compared to other treatments despite the fact that they were of the same crude protein levels ( $45 \% \mathrm{cp}$ ). These might be attributed to good odour, colour and stability in water in line with Dupree and Haylor who reported that color and odour attract cultured organisms to pelleted feed.

High weight gain, Protein efficiency ratio, Food conversion ratio, Average daily weight gain and highest Specific growth rate was recorded from fish fed Treatment 3 (15\% fishmeal and 15\% grasshopper meal). This is related to Gbadamosi et al. [24] who recorded high weight gain, specific growth rate and food conversion ratio from Clarias gariepinus post juvenile fed with ration of $42 \%$ crude protein at $50 \%$ mixture level. Treatment 4 (10\% fishmeal and 20\% grasshopper meal) and Treatment 5 (30\% grasshopper meal) have a lower weight gain, protein efficiency ratio, food conversion ratio, specific growth rate and average daily weight gain when compared with Treatment 1,2 and 3.

Okoye and Nnaji [20] reported that the inclusion of $10 \%$ grasshopper meal with $30 \%$ fishmeal gave a better growth performance than the diet with $40 \%$ fishmeal and no grasshopper meal. This is as a

\begin{tabular}{|c|c|c|}
\hline Treatments & Fishmeal inclusion (\%) & Grasshoppermeal Inclusion (\%) \\
\hline 1 & 30 & - \\
\hline 2 & 20 & 10 \\
\hline 3 & 15 & 15 \\
\hline 4 & 10 & 20 \\
\hline 5 & - & 30 \\
\hline
\end{tabular}

Table 3: Experimental Design with Grasshopper/ Fishmeal inclusion in the diets 
Citation: Olaleye I.G (2015) Effects of Grasshopper Meal in the Diet of Clarias Gariepinus Fingerlings. J Aquac Res Development 6: 321 . doi: 10.4172/2155-9546.1000321

Page 3 of 3

\begin{tabular}{|c|c|c|c|c|c|c|}
\hline Sample & \%dry matter & \%moisture content & \%crude protein & \%ether extract & \%Ash & \%Crude fibre \\
\hline Grasshopper meal & 94.9 & 5.1 & 64.51 & 12.0 & 1.0 & 17.0 \\
\hline
\end{tabular}

Table 4: Proximate analysis of Grasshopper meal

\begin{tabular}{|c|c|c|c|}
\hline Sample & \%calcium & \%phosphorus & \%sodium \\
\hline Grasshopper meal & 0.55 & 0.12 & 0.1 \\
\hline
\end{tabular}

Table 5: Essential mineral content of Grasshopper meal

\begin{tabular}{|c|c|c|c|c|c|c|c|c|c|}
\hline Treatment & Initial weight(g) & Final weight(g) & Weight gain(g) & TFC(g) & ADG(g) & SGR(g) & FCR(g) & PER(g) & \%Survival rate \\
\hline 1 & 15.60 & $60.50 \mathrm{~b}$ & $44.90 \mathrm{~b}$ & $85.12 \mathrm{~d}$ & $0.80 \mathrm{~b}$ & $0.024 \mathrm{~b}$ & $1.90 \mathrm{~d}$ & 0.99 & $80 \mathrm{a}$ \\
\hline 2 & 19.45 & $71.75 \mathrm{a}$ & $52.30 \mathrm{a}$ & $118.72 \mathrm{a}$ & $0.93 \mathrm{a}$ & $0.024 \mathrm{~b}$ & $2.26 \mathrm{~b}$ & $1.16 \mathrm{a}$ & $70 \mathrm{~b}$ \\
\hline 3 & 16.50 & $65.65 \mathrm{~b}$ & $49.15 \mathrm{~b}$ & $107.8 \mathrm{~b}$ & $0.88 \mathrm{~b}$ & $0.025 \mathrm{a}$ & $2.14 \mathrm{c}$ & $1.10 \mathrm{~b}$ & $75 \mathrm{~b}$ \\
\hline 4 & 19.10 & $58.80 \mathrm{c}$ & $39.75 \mathrm{c}$ & $92.26 \mathrm{c}$ & $0.71 \mathrm{c}$ & $0.020 \mathrm{~d}$ & $2.32 \mathrm{a}$ & $0.89 \mathrm{~d}$ & $65 \mathrm{c}$ \\
\hline 5 & 16.35 & $53.90 \mathrm{c}$ & $37.55 \mathrm{c}$ & $79.10 \mathrm{c}$ & $0.67 \mathrm{~d}$ & $0.022 \mathrm{c}$ & $2.10 \mathrm{c}$ & $0.84 \mathrm{~d}$ & $80 \mathrm{a}$ \\
\hline
\end{tabular}

Table 6: Feed utilization and survival of Clarias fingerlings fed with five different diets for 56 days

result of good quality essential amino acid present in both feedstuffs when combined.

Little mortality was recorded in all the treatments as a result of improper acclimatization and low temperature during the first 2 weeks (which was between $21-23^{\circ} \mathrm{C}$ ) of the study. This is in line with Falayi $[2,3]$ who say that warm water fish grows best at temperatures between $25-32^{\circ} \mathrm{C}$.

\section{Conclusion}

A lot of research had been carried out on suitable substitutes for fishmeal in fish diet. Grasshoppermeal has been shown to contain most of the essential amino acids in higher proportions than other protein feedstuff like bloodmeal, groundnut cake and soybean meal.

The growth performance of Clarias gariepinus fed with five different diets containing grasshoppermeal at varying inclusion level was monitored for 56 days in net hapas installed in concrete tank. The overall best performance was obtained in treatment 2 and 3 respectively. This is an indication of the potentials of grasshopper meal to substitute fishmeal for Clarias gariepinus to achieve optimal growth.

Based on the result obtained, more studies should be carried out on other conventional feedstuffs of least cost for growth performance of Clarias gariepinus and possibly other aquacultural fish.

\section{References}

1. Ajana AM (2002) Over view highlight and protein of fisheries in Nigerian aquaculture.

2. Falaye BA (2009a) Feed nutrients chemistry and importance in fish and livestock production.

3. Falaye BA (2009b) Tropical feedstuffs composition tables and biological catalogues in fish and livestock production.

4. Salami AA, Balogun OB, Fagbenro, Edibite L (1992) Utilization of non-pituitary extract in breeding of Clarias gariepinus.

5. NRC (1993) Nutritional requirements of warm water fish and shellfishes. National Academy Press. Washington DC, USA.

6. Balogun AM, Ologbobo AD (1989) Growth performance and nutrient utilization of fingerlings of Clariasgariepinus (Burchell) fed raw and cooked soybean diets. Aquaculture 76: 119-126.

7. Sadiku SOE, Jauncy K (1998a) Utilization of enriched soybean flour by Clarias gariepinus. J Aqua Tropics 13: 1-10.

8. Sadiku SOE, Jauncy K (1998b) Digestibility, apparent amino acid availability and waste generation potential of soybean flour-poultry meat meal blend diets for the sharp-toothed catfish fingerlings. J Applied Aquaculture 8: 69-75.
9. Fagbenro OA, Davies SJ (2002) Use of soybean flour (dehulled solvent extracted soybean) as fishmeal substitute in practical diet for African catfish, Clariasgariepinus (Burchell 1822) growth, feed utilization and digestibility. Journal of Applied Ichthyology 17: 64-69.

10. Fagbenro OA, Davies SJ (2003) Use of high percentages of soy protein concentrate as fishmeal substitute in practical diets for African catfish growth, feed utilization and digestibility. Journal of Aquaculture 16: (1).

11. Eyo AA (1994) Fish feed production techniques in agro products.

12. Davies SJ, Fagbenro OA, Abdel-Waritho, Diller I (1999) Use of soybean products as fishmeal substitute in African Catfish Clariasgariepinus, diets. Applied Tropical Agriculture 4: 10-19.

13. Faturoti EO, Oyelese I (1989) Digestibility and utilization of yellow maize and sweet potatoe based diets by Clariasgariepinus.

14. Eyo AA (1999) The effect of different method of soybean processing on the growth and food utilization of African mudfish Clariasanguillaris $(\mathrm{L})$ fingerlings. J Biotech 10: 9-10.

15. Ufodike EBC, Ekotutu PA (1986) Protein digestibility and growth of African catfish fed blood meal and algae diets. Acta hydrobiologica 28: 237-243.

16. Ofojekwu PC, Ejike C (1984) Growth response and feed utilization in tropical Cichlid Oreochromisniloticus (Lin) fed on cottonseed based artificial diets. Aquaculture 42: 27-37.

17. Sharah HA (2012) The driving force behind increasing grasshopper frying business in Maiduguri: Profitability or Joblessness?. Int J Eco Dev Res Invest 3: 110-117.

18. Association of Official Analytical Chemists (A.O.A.C) (1995) Official methods of analysis of A.O.A.C. Washington DC, USA.

19. Njidda AA, Isidahomen CE (2010) Haematology, blood chemistry and carcass characteristics of growing rabbits fed grasshopper meal as a substitute for fishmeal. Pak Vet J 30: 7-12.

20. Okoye FC, Nnaji JC (2004) Effect of substituting fishmeal with grasshopper meal on the growth and food utilization of the Nile Tilapia, Oreochromis niloticus fingerlings.

21. Lopez-Alverado J, Langdon CJ, Teshima S, Kana- Sawa A (1994) Effect of coating and encapsulating of crystalline amino acids on leaching in larva feeds. Aquaculture 122: 335-345.

22. Eyo AA (2001b) Chemical composition and amino acid content of the commonly available feedstuffs used in fish feed in Nigeria.

23. Haruna BA (2003) Aquaculture in the tropics. Theory and practice. Al-Hassana Publishers Abuja, Kaduna, Kano- Nigeria.

24. Gbadamosi OK, Daramola JA, Osungbemiro (2007) Growth performance and nutrional utilization of vitamin $\mathrm{c}$ in diet of African catfish fingerlings. Acta Zoological science 58: 763-766. 